Annals of Warsaw University of Life Sciences - SGGW

Horticulture and Landscape Architecture No 39, 2018: 27-35

(Ann. Warsaw Univ. of Life Sci. - SGGW, Horticult. Landsc. Architect. 39, 2018)

DOI 10.22630/AHLA.2018.39.3

\title{
Landscape as the tool of coherence in the land management of rural communes
}

ANNA GÓRKA

Faculty of Architecture, Gdansk University of Technology

\begin{abstract}
Landscape as the tool of coherence in the land management of rural communes. The economic and social transformation of rural areas in Poland after 1990 reveals itself/can be seen through the disintegration of the previous spatial order. Building a new pattern requires a vision which would counteract the complex causes of the disintegration. The latter belong to the institutional domain of planning strategies and the area of common practices. Therefore, agreement on the aims and means between spatial policy strategies and the tactics of those using the space/spatial use would favour the protection and sustainable shaping of environmental resources. An attempt to merge both the aforementioned life domains may be successfully realised only within the landscape and at the level of the commune, where local development takes place. The present article refers to the symptoms and causes of deformations in the rural landscapes. It describes landscape rurality as the desired development vision and the utility of landscape tools in the space/spatial management of a small commune. The article defines the idea of public space in a landscape aspect and indicates the directions and areas of explorations which would need to be developed according to the suggested perspective.
\end{abstract}

Key words: landscape, rurality, land management

\section{INTRODUCTION}

"only problems which can be seen may also be dealt with" (Usher 2017) ${ }^{1}$

\footnotetext{
${ }^{1}$ From the letter of Richard Feynman to Koichi Mano (1996).
}

The role of the commune as a local government unit lies in fulfilling the needs of the governmental community and all the actions aimed at improving the quality and safety of living, including providing spatial order and environmental protection. At the commune level, both institutional top-down and community bottomup actions and interactions are realised and then units affect them. The commune receives the effects of external - national and global - conflicts. Economic and social initiatives are created and developed in a favourable local environment. The quality of space in the commune faithfully reflects the entangled internal and external social phenomena. Therefore, the general concepts of landscape management and its protection need to be considered mainly towards the public policy of communes. This rather obvious statement has significant consequences for managing space in Poland, particularly in rural communes, which since the 1990s have remained a traverse of the political, economic and cultural transformation of an unstable and discordant image (Kowalewski et al. 2013).

The aim of the current article is to prove landscape utility as a tool in the public policy of rural communes, initiating special integrity. Firstly, a phenomenon of landscape disintegration in rural 
areas is described. Secondly, a preventive concept is presented. It is also proven how forming local development visions can be used and why it is important to base them on the rurality image. The significance of landscape for rurality and the role of landscape design in the integrated management of commune space are also described. Finally, an attempt to root the participation of landscape instrumentation in the participatory space management is made.

\section{SPATIAL ORDER} DESINTEGRATION OF RURAL AREAS

The structures of non-agricultural functions and new arrangement of public places constitute visible, spatial signs of social and economic transformations. The current estates of migrants or holiday settlements, thematic villages, logistic centres, communication infrastructures and urbanised public spaces introduce a community system of values different to those developed by the agricultural community and disassemble the established order of the rural space. Experts indicate the participation of two processes: farming modernisation, which has led to diminishing the number of agricultural employees and excluding large plots from production, as well as to the influx of people from cities. However, the growing migration to and multi-functionality of the countryside do not result directly from the market opportunity given to other functions by the retiring agriculture or political support mechanisms (such as the Rural Areas Development Programme). The increase in demand for rural building areas is also a differetiator of the changing expectations of the urban middle class towards their lifestyles. They refer to healthy eating, physical activity, a clean environment and close contact with nature. These features are permanently associated with the countryside and more and more commonly desired.

Many analysts notice an ill-balanced course of spatial transformation of the rural areas. They mostly emphasise the irrational (in the long run) spatial policy of the communes (Śleszyński et al. 2007, Kowicki 2014). In the experts' opinions excessive dispersion and fragmentation of building development increases the costs of both the technical and social infrastructure and transport. They also restrict agricultural productivity and burden sensitive meadow ecosystems. They are a source of threats to health and life due to the risk of traffic accidents and increase of environmental pollution, as well as rapid natural phenomena (such as floods and landslides) and worsening weather or water conditions. They cause the loss of visual qualities of the surroundings and diminished tourist attractions. They favour a decentralisation of activity (e.g. places to work, spend free time or study), which inhibits the local community integration, the creation of a new territorial identity among migrants and causes an increase in social exclusion.

At the same time, the built up rural environment with its decreasing number of farms is subject to urbanisation. It offers fewer smells, tactile sensations and activities linked to agriculture and nature. This restricts the scope of individual and social experiences and reduces 
the choice of lifestyles in the future. Altogether it causes that predictable costs of changes, including lost possibilities of future development, significantly exceed the currently achieved profits. The decisions of local governments, made with the influence of opinions and operating economic needs, remain in blatant contradiction with the constitutional aim of the social and economic policy of the Republic of Poland, i.e. with the principle of sustainable development (Art. 5 of Polish Constitution), which prescribes to optimise environmental and social profit and loss towards achieving a high quality of present and future life.

The assumption that a spatial policy of the communes that is destructive for life results only from managerial mistakes or speculations would be preposterous considering the common character of the described phenomena. It is necessary to search for more basic reasons, which may be found in the deep discrepancy of two inherent spheres of social life, namely the institutional and individual ones (Sikora 2014). Local governments create the legal framework for individual investment activity. They are a part of the democratic system of the country; they manage the space by using the normative tools of the spatial planning system and realise the aims of the government and the inhabitants. Each decision, both within the public area and everyday life are not made by the system but man, who weighs the benefits and costs - both the measurable and the uncountable. Man makes a choice guided by their own experience: gained knowledge, convictions or habits, association or emotions. If the acquired tactics deny the orderly political idea (Certeau 2008,
Sztompka 2016), it is the beginning of a conflict, finally perceived as a lack of spatial order.

In light of the cited facts and judgements, the likely, though deeply hidden source of the conflict, is rooted in the public domain. This thesis is supported by the social illegibility of spatial concepts which refer to sustainability. This matter does not include communication, and therefore agreement between institutions and individuals. One side of the scene involves the acting fragmentary and disintegrated legal operations of a system managing the built up environment, namely studies of the conditions and directions of spatial development, local plans, protection plans, conservation guidelines, environmental impact assessment, energetic audit, building permits etc. (What draws attention is the lack of a real - as opposed to a dummy - support mechanism of a social dialogue included in the system, which would incorporate the strategic principle of sustainable development. Sometimes reliable consultations of local plans are conducted owing to the support of non-governmental organisations. An example is a project of the "Our Space. Our Deal" Foundation for Rural Support, realised since 2015). On the other side of the stage there are individuals, unconscious of the threats and postponed consequences of their own spatial decisions, who therefore take an extremely pragmatic attitude both in their private life and public matters. An obvious conclusion is that the successful realisation of strategic aims (offered by intellectual elites based on the current knowledge and the common wealth principle) requires procedures and tools which could become a clear carrier of a 
commonly recognised and accepted development vision.

\section{LANDSCAPE RURALITY AS A COHERENCE FACTOR}

Nowadays, the rationale of the country is based on its rurality (Wilczyński 2013, Górka 2016). Transformation of the rural economy and lifestyle changes are reasons it should be perceived as landscape specific, distinguishing the countryside from the city. The rural character of the countryside involves spatial features and relations shaped in the course of the rural usage. It is also made of common images (Taylor 2001), induced by direct and indirect experiences (Berleant 2011), which decide on perceiving spatial features as rural ones.

The rurality of the landscape is a kind of image, which may be easily interpreted by the community as different from the urban due to e.g. the quantity and species composition of the greenery; type, scale, intensity, construction or detail of the development; accessibility of open landscapes; mutual relations between the greenery, development and topography; the dominant colour; presence of animals, etc. However, the desired rurality should not be defined only by means of those features and relations of a distanced view. The image of the surroundings, which we "keep in mind", may be a significant carrier of various kinds of information on the mutual environment-human influence. The condition of the observed elements of the landscape reflects the quality of the multidimensional relations between them. The commonly recalled expressions, such as "peace and quiet", "clean air", "beautiful landscape", "healthy products", "rural heritage", "close contact with nature" (Zawadka 2013) or - more rarely - "close relations with people" are used to characterise the rural environment. The protection of these valued features is closely linked to following the rules of energetic effectiveness and using technologies restricting emissions (European Commision 2014), counteracting against social exclusion and providing access to enjoyable gardening or the possibility to choose a walking route. The examples of projects aimed at protection of these cited features of the rural space are: local production and distribution of regional building materials, development of ecological agriculture, preventing scattered building development or implementing a native planting policy, etc.

The idea of landscape rurality covers images, knowledge-based opinions and experiences, and emotions resulting from physical involvement in the environment. At the same time, it has the opportunity to build a connection between the image of a rural landscape and the ecological, social, economic and perceptive prerequisites of its shaping - a specific, holistic environmental awareness.

\section{NEGOTIATING THE LANDSCAPE FEATURES}

The way the landscape is perceived depends on the viewers: their private stories, gained knowledge, opinions, habits and intentions, as well as their sensual experiences, appearing in the environment. Therefore, the same view may be perceived differently. It is influenced by 
the optics principles, but also a collection of associations induced by the landscape stimuli. According to Meining (1979), observers interpret the landscape as nature, history, habitat, artifact, economic value, issue, ideology or system. As they do it depending on different experiences and intentions, various strategies are implemented. Rapoport (1990) presents a similar opinion, noticing that conflicting spatial actions result from different assessments of the surroundings and situations, as well as the contradictory aims of those who start them. As space users/users of space we are stuck mainly in the landscape: through visual and corporal experiences, work, emotions, memory, knowledge, beliefs and images. The landscape perceived directly and in representations remains the only accessible and as such holistic medium of communicating the individual and collective meanings of the environment, its images and visions, and therefore it is the best of all possible common grounds. Consequently, social landscape policies, using these images and referring to experiences, would simplify the establishment of attitudes and building a common idea of spatial action in counties/communes (such as commercials in the case of spreading fashion tendencies).

The high negotiating competencies of the landscape decide on its usage in creating the images of the place by the community. Such collective images direct the development and limit the risk of local conflicts in managing space (Pawłowska 2008). Therefore, they constitute the basic prerequisite of preserving continuity, identity and coherence by the community. The creation of image has to be preceded by a collective identifica- tion of the surrounding spatial features and their imaging on maps, drawings or photographs. The common recognition of qualities in the inhabited area favours social integration around these values and encourages participation in their development. Clifford and King (1996) emphasises the significant meaning of the process of creating so-called parish maps. "Saving" important places and collecting familiar details (stories, legends, objects related to a certain lifestyle, known people) reveals unique relations between a territory and its inhabitants. It also supports their actions made to preserve identity and improve the quality of life. What is more, it brings a lot of joy to everyday life. Only the community which gives its territory the range of a common ground and makes it a subject of collective knowledge, activity and responsibility has a chance to safely direct its transformations. The base of the process is a common judgement and image, which then transfers to the integrity of the spatial management.

\section{THE TOOL OF THE LANDSCAPE IN RURAL COUNTY SPACE MANAGEMENT}

Nowadays, there are two approaches to the landscape, and they stem from the 19th century. These are the protection paradigm and the consumption paradigm. The birth of the first was linked to building national countries. The latter is based on the domination of vision and images, and characteristic for the whole of western culture; tourism refers to this approach as well. Both perspectives treat the landscape as a form of the past. The 
uniqueness of its elements - objects, places and areas - decides on their protection and attractiveness for consumers. As a result, only chosen, rare objects, and not integral entireties and phenomena are protected and perceived as valuable. The features and relations of common places, without exceptional elements, but with preserved specifics of traditional spatial relations and a harmonious landscape, are not treated as worth preserving. As a result, they are not reproduced in the course of usage and then they disappear.

Both the cited approaches above ignore the landscape creators and their constant input into its change. Indeed, there is no possibility to protect the unchanged past at present. Even the selection of protected elements is arbitrary and depends on the past created for the use of our times (Ashworth 2015). This is proven by the contemporary products of rural tourism, which creatively refer to chosen elements of the popular folklore and history of the country. It is therefore impossible to treat the landscape only as a type of preserved resources, subject to protection and consumption. The landscape is changeable and constantly produced. It has real and mental dimensions. It is not only a form but also a social process including a constant creation of new structures and values; a process which can be managed. Moreover, the landscape being simultaneously a material subject of action, its conditioning and effect, determines the integrity of the social life. The physicality and visuality of the landscape ensure the legibility of its planning and course, and therefore favour communication and social engagement. The assessment of the landscape's character may combine visual perception and impressions, as well as the functioning of ecosystems, technical and social structures. It allows to recognise and compare the quantitative and qualitative costs and benefits of the planned transformations in a better way. The conducted discussion results in a statement that designing the landscape as a social process may be a kind of integrated public policy and an effective tool in achieving spatial order.

The role of landscape design, considered as managing a built up environment, would be a creation of a coherent character and of a visual shape of places. The image of a place is a social value. It builds the impression of durability which the continuity of the community depends on. This statement is particularly directed to the design of public spaces, including streets and rural squares, recreation areas (Górka 2012) and open landscapes. The standardisation of common areas and limitation of access to open landscapes are sources of spatial and social disintegration, as they inhibit the elaboration of a unique image of a place (as a territory with known borders) by the local community. The aim of the design of common places should be their landscape specifics, compliant with the development vision established by its inhabitants.

A mission of the design of public spaces formulated in such a way is associated with the postulate of science. It would be necessary to start research over the integrated assessment of landscape quality method. This kind of judgement should take collective images and opinions into account and compare space user's expectations with their satisfaction. The connections between common spatial use, land development, as well as features and relations of the natural en- 
vironment, should be searched for. The results should be applied at the local level. It is particularly important to stop the progressing unification and primitive urbanisation of many villages (Figs. 1,2).

Management of the built up environ-

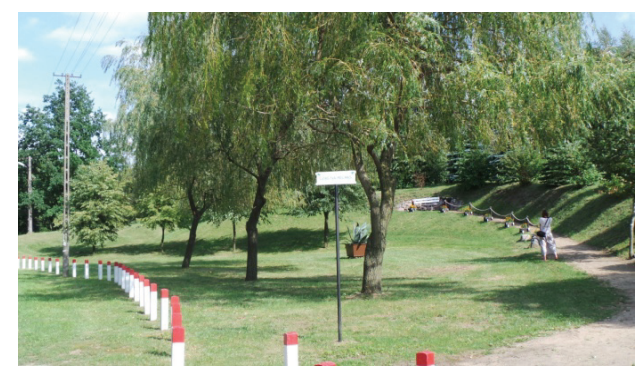

FIGURE 1. Common space, Brzeźno Wielkopolskie, Pomorskie Voivodeship, Poland (photo by A. Górka)

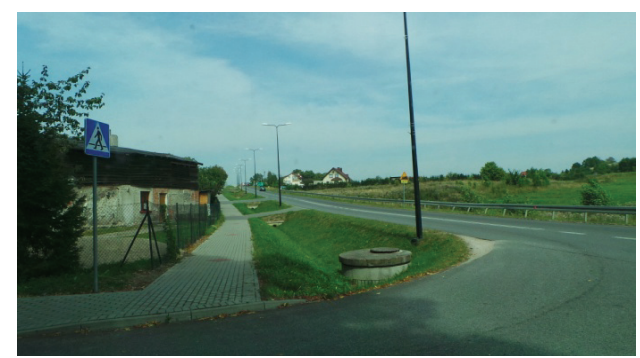

FIGURE 2. Nobody's space, Rybno, Pomorskie Voivodeship, Poland (photo by A. Górka)

ment through designing the landscape requires an expansion of its instrumentation. The need for counteracting fragmentation and providing integrity at the commune and town levels is the reason why the landscape as a tool may be potentially used bidirectionally and simultaneously in (a) top-down and (b) bottom-up approaches. Records of local plans have to realise the mental and image vision established by the community. This is created as a result of external stimulation and the bottom-up recognition of territory resources.

The legal system of public planning in communes should be complemented by the concept of shaping the landscape's character, which would serve co-ordinating and integrating roles, as well as by a collection of dissemination developments (so-called good manuals), which would thoroughly and vividly present and explain the aims and principles of sustainable spatial policies in different aspects of life (e.g. the connection between developing common spaces with the aims of rain water management or the influence of wayside and private garden planting on saving energy, etc.). On the basis of reliable social consultations, communes would be responsible for recognising the attitudes of space users and conducting series of training sessions, workshops and meetings dedicated to negotiating a consensus. A True process of social consultation, covering opinion surveys, presenting developed plans, finding agreement and a final choice of spatial solutions, definitely needs an expanded (digital and traditional) visualisation mechanism, which would include photographs, various cartographic developments, hand sketches or models. By using landscape instrumentation, the local government would more successfully realise the established sustainability strategy and stimulate desired changes.

The aim of the bottom-up approach in landscape management would be to build social (civic and educational) attitudes toward the process, and particularly a community-developed, specific set of images, opinions, beliefs and habits related to its surroundings. It would involve a collective, landscape model, 
with specified forms and functions and spatial relations. It would constitute a certain desired pattern or reference for the conducted investment actions. A common drawing of mental maps of town, student or civic landscape (ECOVAST 2006), thematic exhibitions of town photographs and drawings, various performative events, and finally participatory planning and plans' implementation would allow to create or reveal and continue the landscape expectations, beliefs and associations of individuals and groups, which is a preliminary condition to establishing the local principles of shaping space by the community. These actions would develop "thinking through landscape" and "landscape awareness", give the opportunity to communicate aesthetical judgements and lay the foundations to local spatial culture. They would allow to set a base of social trust and local knowledge towards building an agreement platform regarding issues of development directions and spatial development. It is a domain of a so-called third sector (i.e. non-governmental organisations) and informal leaders.

\section{CONCLUSIONS}

Landscape protection and management cannot remain the only domain of the legislator and professionals. If this is the case, their actions are doomed to failure or only temporary effects. The landscape is a mirror, reflecting the linked results of political strategies and common investment practices. As a distorting mirror, it deforms political ideas, transferred to the educationally and consciously unprepared social ground. The restoration of spatial order in the communes should be, then, started from establishing the social development vision, aligned with local images and opinions and consistent with the top assumptions. The harmonisation of political ideas and spatial images, the judgements and habits of people, would have to be entrusted with a landscape instrumentation which could be the most effective tool of coherence in the spatial policies of the communes. Its implementation to the land management system depends on the government's initiative, but its effectiveness depends on civic awareness and participation. Both landscape approaches - top-down and bottom-up - lead to establishing local principles of the sustainable management of rural areas, supporting the identity, integrity and durability of the local communities.

\section{REFERENCES}

ASHWORTH G. 2015: Planowanie dziedzictwa. Wydawnictwo MCK, Kraków.

BERLEANT A. 2011: Wrażliwość i zmysły. Estetyczna przemiana świata człowieka. Wydawnictwo Universitas, Kraków.

CERTEAU M. 2008: Wynaleźć codzienność. Sztuki działania. Wydawnictwo Uniwersytetu Jagiellońskiego, Kraków.

CLIFFORD S., KING A. (Eds.) 1996: From place to place: maps and parish maps. Common Ground.

ECOVAST 2006: Landscape Identification. A Guide to Good Practice. Retrieved from: www.ecovast.org/papers/good guid_e.pdf.

European Commision 2014: Programme of Infrastructure and Environment 2014-2020 . Brussels.

GÓRKA A. 2012: Krajobrazy przestrzeni publicznych wsi. Zagadnienia projektowania i planowania ruralistycznego. Wydawnictwo Politechniki Gdańskiej, Gdańsk. 
GÓRKA A. 2016: Krajobrazowy wymiar ruralistyki. Wydawnictwo Politechniki Gdańskiej, Gdańsk.

KOWALEWSKI A., MORDASEWICZ J., OSIATYŃSKI J., REGULSKI J., STĘPIEŃ J., ŚLESZYŃSKI P. 2013: Raport o ekonomicznych skutkach i społecznych kosztach niekontrolowanej urbanizacji w Polsce. IGiPZ PAN, Fundacja Rozwoju Demokracji Lokalnej, Warszawa.

KOWICKI M. 2014: Rozproszenie zabudowy na obszarach Małopolski a kryzys kreatywności opracowań planistyczno-przestrzennych. Wydawnictwo Politechniki Krakowskiej, Kraków.

MEINIG D.W. 1979: The Beholding Eye: Ten Versions of the Same Scene. In: D.W. Meinig, J.B. Jackson (Eds.) The Interpretation of Ordinary Landscapes: Geographical Essay. Oxford University Press, New York.

PAWŁOWSKA K. 2008: Przeciwdziałanie konfliktom wokół ochrony i kształtowania krajobrazu: partycypacja społeczna, debata publiczna, negocjacje. Wydawnictwo Politechniki Krakowskiej, Kraków.

RAPOPORT A. 1990: The Meaning of the Built Environment: A Nonverbal Communication Approach. University of Arizona Press [reprint 1982]. Sage Publications, Beverly Hills.

SIKORA M. 2014: Modele sfery publicznej w świetle współczesnych problemów społecznych. Filo-Sofija 24: 43-63.

SZTOMPKA P. 2016: Kapitał społeczny. Teoria przestrzeni międzyludzkiej. Znak, Kraków.

ŚLESZYŃSKI P., BAŃSKI J., DEGÓRSKI M., KOMORNICKI T., WIĘCKOWSKI T. 2007. Stan zaawansowania planowania przestrzennego w gminach. Prace Geograficzne 211. IGiPZ PAN, Warszawa.

TAYLOR Ch. 2001: Nowoczesne imaginaria społeczne. trans. from English A. Puchejda, K. Szymaniak. Znak, Kraków.

USHER S. (Ed.) 2016: Listy niezapomniane. Vol. 2. Trans. from Englih J. Małecki. SQN, Kraków.
WILCZYŃKI R. 2013: Podejścia top-down i bottom-up w rozwoju obszarów wiejskich w Polsce. In: K. Heffner (Ed.) Rozwój obszarów wiejskich w Polsce a polityka spójnościi Unii Europejskiej: stare problemy i nowe wyzwania ze szczególnym uwzględnieniem woj. opolskiego. Studia KPZK PAN 154: 72-82.

ZAWADKA J. 2013: Opinie, preferencje, zachowania i oczekiwania turystyczne mieszkańców miast względem agroturystyki. Studia KPZK 162 (8): 139-153.

Streszczenie: Krajobraz jako instrument spójności w zarzqdzaniu przestrzeniq gminy wiejskiej. Transformacja gospodarcza i społeczna obszarów wiejskich w Polsce po 1990 roku ujawnia się poprzez rozpad dotychczasowego porządku przestrzennego. Budowanie nowego ładu potrzebuje wizji, która przeciwdziałałaby złożonym przyczynom dezintegracji. Należą one do instytucjonalnej sfery strategii planistycznych oraz do obszaru codziennych praktyk. Stąd wniosek, że uzgodnienie celów i środków między strategiami polityki przestrzennej oraz taktykami użytkowników przestrzeni sprzyjałoby ochronie i zrównoważonemu kształtowaniu zasobów środowiska. Podejście, które scali obie wymienione płaszczyzny życia, może być skutecznie realizowane jedynie na płaszczyźnie krajobrazu oraz na poziomie gminy, w której przebiega rozwój lokalny. Treścią artykułu są przejawy i przyczyny deformacji krajobrazów wiejskich. Opisana została wiejskość krajobrazu w roli poszukiwanej wizji rozwoju oraz użyteczność narzędzi krajobrazu w zarządzaniu przestrzenią małej gminy.

Słowa kluczowe: krajobraz, wiejskość, zarządzaniu przestrzenią

MS received: 26.07.2017

MS accepted: 14.05 .2018

\section{Author's address:}

Anna Górka

Katedra Projektowania Środowiskowego

Wydział Architektury

Politechnika Gdańska

e-mail: anna gork@interia.pl 